\title{
Numerical Simulation of a Batch-Type Reheating Furnace
}

\author{
Francisco J. Nava, Miguel A. Barron, Dulce Y. Medina \\ Departamento de Materiales, Universidad Autonoma Metropolitana Azcapotzalco, Ciudad de Mexico, Mexico \\ Email:bmma@correo.azc.uam.mx
}

How to cite this paper: Nava, F.J., Barron, M.A. and Medina, D.Y. (2018) Numerical Simulation of a Batch-Type Reheating Furnace. World Journal of Engineering and Technology, 6, 713-722. https://doi.org/10.4236/wjet.2018.64046

Received: August 20, 2018

Accepted: September 24, 2018

Published: September 27, 2018

Copyright (c) 2018 by authors and Scientific Research Publishing Inc. This work is licensed under the Creative Commons Attribution International License (CC BY 4.0).

http://creativecommons.org/licenses/by/4.0/

(c) (i) Open Access

\begin{abstract}
A numerical analysis of a batch-type reheating furnace with and without thermal load was carried out using the Computational Fluid Dynamics technique. The furnace has two premixed burners and methane is used as fuel. Previous to the numerical experiments, a mesh convergence test was carried out and the average internal furnace temperature and the exhaust gases temperature were monitored as function of the number of cells in the discretized system. The influence of the Air/Fuel ratio, the position of the burners, and the thermal load on the average internal temperature, the exhaust gases temperature, and the molar fraction of methane and oxygen in the exhaust gases was numerically explored.
\end{abstract}

\section{Keywords}

Air/Fuel Ratio, CFD Simulation, Exhaust Gas, Numerical Simulation, Premixed Burner, Reheating Furnace, Thermal Load

\section{Introduction}

In the steelmaking industry, reheating furnaces are used to heat the steel semi-finished products, namely billets, bloom and slabs, to temperatures of around $1200^{\circ} \mathrm{C}$ which are suitable for plastic deformation and rolling. The heat for a reheating furnace comes from the combustion of solid, liquid or gaseous fuels with oxygen contained in air. Heat is transported to the solid charge by means of convection and radiation from the burner gases and the furnace walls [1]. There are batch-type and continuous-type reheating furnaces, depending on the tonnage and size of the solid charge.

In the last years several reports have been released in which reheating furnaces and other combustion furnaces are numerically analyzed through the Computational Fluid Dynamics (CFD) technique. In [2] the fundamentals of mathemati- 
cal modeling for industrial furnaces and boilers using CFD are described. The main objective of [2] was to employ CFD as an effective computer simulation tool to study and develop the new combustion concepts, phenomena and processes in advanced industrial furnaces and boilers.

In [3] the main parameter considered is the excess air ratio, which is used to study the temperature distribution. According to the author, the reported CFD calculations showed a good agreement with the measured experimental data both in full and pilot scale of the test furnace as well as from the literature data. In [4] a CFD analysis has been conducted to examine the transient and three dimensional temperature fields in a prototype of a reheating industrial furnace aimed to maximize the furnace performance. The report included different burner designs, fuel flow rates, and combustion air supplies.

The paper [5] discusses the benchmarking of a CFD analysis for the operation of a combustion furnace. According to the authors, the heating profile is reasonably well predicted by the simulation. Through the CFD simulations the surface temperature and the temperature within the metal components could be simulated and properly calculated. In [6] results are presented of a numerical CFD study performed for four different burner configurations in a furnace equipped with three pairs of flameless combustion burners firing natural gas. It is reported that the simulations were validated against results of an experimental study, and that the main furnace performance was consistently reproduced for all the considered burner configurations.

In this work a batch-type reheating furnace with two premixed burners is numerically simulated using the CFD technique. Methane is used as fuel. The influence of the Air/Fuel ratio, the position (height from the furnace bottom) of the burners, and the thermal load on the average internal temperature, the exhaust gases temperature, and the molar fraction of methane and oxygen in the exhaust gases is numerically explored. It was found that burner position does not change in a significant way the methane and oxygen molar fraction in the exhaust gases, and that the exit temperature is greater than the average internal temperature until a certain critical value of the Air/fuel ratio is reached.

\section{The Considered Furnace}

Figure 1 depicts the batch-type reheating furnace here considered. It has two premixed burners, an exit for the exhaust gases located at the roof, and the solid charge, which constitutes the thermal load, is located on the floor. The furnace is fired with methane as fuel, and this fuel is burned with ambient air. For the analysis, the methane volumetric flow rate is kept constant at $2.2 \mathrm{Nm}^{3} / \mathrm{h}$ at each burner. For methane combustion, the theoretical air (TA) is 9.52, which means that $1 \mathrm{Nm}^{3}$ of methane requires $9.52 \mathrm{Nm}^{3}$ of air for stoichiometric combustion, considering that air contains $21 \%$ in volume of oxygen. The assumed values of the Air/Fuel (AFR) ratio were 5, 6, 7, 8, 9.52, 10, 14 and 18, which ranges from incomplete combustion for AFR $<$ TA, to lean combustion for AFR $>$ TA. Air 


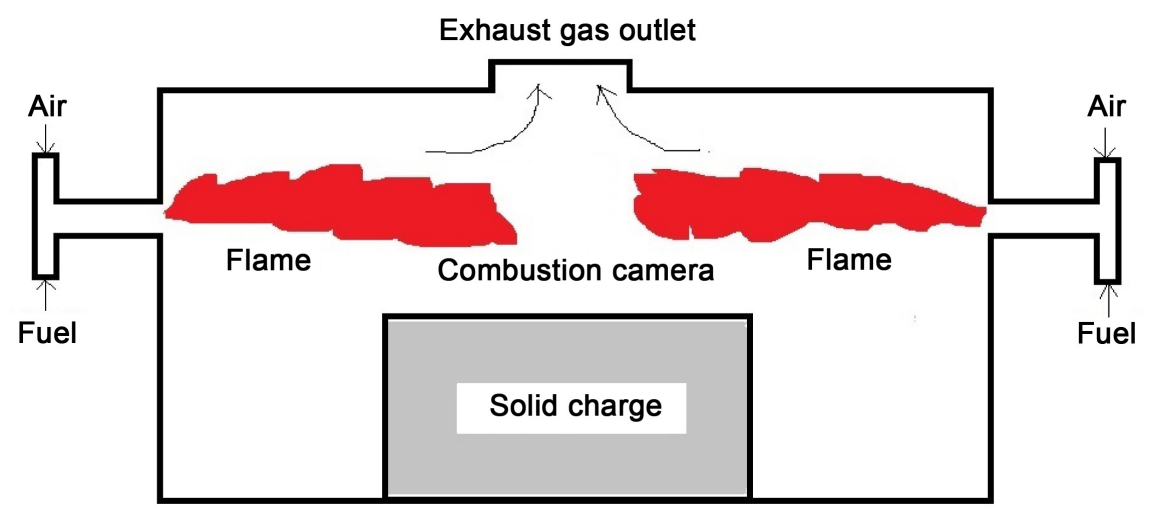

Figure 1. The considered two-burners batch-type reheating furnace.

and fuel are mixed before entering into the furnace.

The solid charge, or thermal load, is heated mainly by radiation from the flames and walls of the furnace, and by convection by the hot combustion gases. The furnace walls are assumed adiabatic, i.e. there is not heat loss through them. Table 1 shows the main physical dimensions of the furnace. Three positions (height from the floor) of the burners are considered, namely 1.2, 1.4 and $1.6 \mathrm{~m}$. Given that the height of the solid charge is $1 \mathrm{~m}$, it is inferred that for the first burner position, $1.2 \mathrm{~m}$, the solid charge is directly exposed to the burner flame, and in this case the heat transfer from the flame to the solid charge could be maximum.

\section{Mathematical Model}

The mathematical model of the combustion in the furnace consists in the conservation of momentum, mass and energy equations. These equations are known since long time ago, and are named as the Navier-Stokes, the continuity and the energy equations [7]. Also, a chemical species balance is required to determine the products of combustion and its molar concentration in the furnace interior and in the exhaust gases. Besides, to simulate the turbulence of the combustion gases, the $K$ - $\varepsilon$ model was selected [8]. Boundary conditions for $K$ and $\varepsilon$ at the inlet nozzles were calculated from $K_{i n}=0.01 U_{i n}^{2}$ and $\varepsilon_{i n}=2 K_{i n}^{3 / 2} / D_{n}$ where $U_{i n}$ and $D_{n}$ are the inlet nominal velocity and the burner nozzle diameter, respectively. For the pressure-velocity coupling, the Pressure Implicit with Splitting Operations (PISO) algorithm was employed [9].

\section{Computer Simulations}

The steady state coupled partial differential equations that constitute the mathematical model were discretized in a $2 \mathrm{D}$ mesh and then were numerically solved using commercial CFD software. Previous to the numerical experiments, a mesh convergence test was carried out. The average internal furnace temperature and the exhaust gases (exit) temperature were monitored as function of the number of cells in the discretized system. The test was stopped when the difference between the temperature readings obtained with two consecutive meshing 
Table 1. Physical dimensions of the furnace.

\begin{tabular}{cc}
\hline PARAMETER & VALUE \\
\hline Length, $\mathrm{m}$ & 4 \\
Height, $\mathrm{m}$ & 2 \\
Thermal load length, $\mathrm{m}$ & 2 \\
Thermal load height, $\mathrm{m}$ & 1 \\
Gas outlet diameter, $\mathrm{m}$ & 0.3 \\
Number of burners, $\mathrm{m}$ & 2 \\
Burner nozzle diameters, $\mathrm{m}$ & 0.088 \\
Height of burners from the floor, $\mathrm{m}$ & $1.2,1.4,1.6$
\end{tabular}

was less than $0.2 \%$. Results of the convergence test are shown in Table 2. Given that the meshing schemes 6 and 7 of Table 2 fulfill the convergence test, scheme 6 was chosen for meshing the system.

In the subsequent numerical experiments, 1) the Air/fuel ratio was varied from 5 to 18,2 ) the burner height took the values $1.2,1.4$ and $1.6 \mathrm{~m}$, and 3) the thermal load was varied from 80,000 to $120,000 \mathrm{~W} / \mathrm{m}^{2}$. As was specified above, the furnace walls were considered adiabatic. The monitored variables were a) the average internal temperature in the furnace, $b$ ) the exhaust gases (named exit in figures) temperature, and c) the oxygen and methane molar fractions in the exhaust gases.

\section{Results in Absence of Thermal Load}

Figures 2-4 show the molar fraction of methane and oxygen in the exhaust gases as function of the Air/Fuel ratio in absence of thermal load for the corresponding burner height. In the three aforementioned figures, the molar fraction of methane decreases as the Air/Fuel ratio (AFR) is increased. Methane is expelled in the exhaust gases for an AFR less than the theoretical air (TA, where AFR = 9.52). In this case there is not enough oxygen to oxidize the fuel and some unburnt methane is present in the exhaust gases. As expected, the molar fraction of methane in the exhaust gases becomes null as the AFR is greater than the theoretical air (TA). However, when AFR > TA, oxygen is present in the exhaust gases, as is observed in the above figures. From these figures, no significant influence of the burner (height) position on the exhaust gas composition is inferred.

Figures 5-7 show the exhaust gas (exit) temperature and the average internal temperature in the furnace as function of the Air/Fuel ratio for the several positions (height) of the burners. From these figures, the following comments arise irrespective of the burner position: 1) both temperatures are increased as AFR < $\mathrm{TA}$; 2) both temperatures arrive to a maximum value at $\mathrm{AFR}=\mathrm{TA} ; 3$ ) both temperatures decrease for AFR $>$ TA. From the above figures it can be noted that the exit temperature is greater than the average internal temperature until a certain value of AFR (here named critical value, AFRC) is reached. For AFR > 
Table 2. Mesh convergence test.

\begin{tabular}{cccc}
\hline MESHING & $\begin{array}{c}\text { NUMBER OF } \\
\text { CELLS }\end{array}$ & $\begin{array}{c}\text { INTERNAL } \\
\text { TEMPERATURE, } K\end{array}$ & $\begin{array}{c}\text { EXHAUST GAS } \\
\text { TEMPERATURE, } K\end{array}$ \\
\hline 1 & 850 & 2489.6 & 2635.5 \\
2 & 1670 & 2478.7 & 2632.8 \\
3 & 4574 & 2364.6 & 2598.3 \\
4 & 5960 & 2321.5 & 2579.5 \\
5 & 7904 & 2283.8 & 2562.3 \\
6 & 12,578 & 2250.7 & 2543.0 \\
7 & 15,534 & 2247.4 & 2545.7 \\
\hline
\end{tabular}

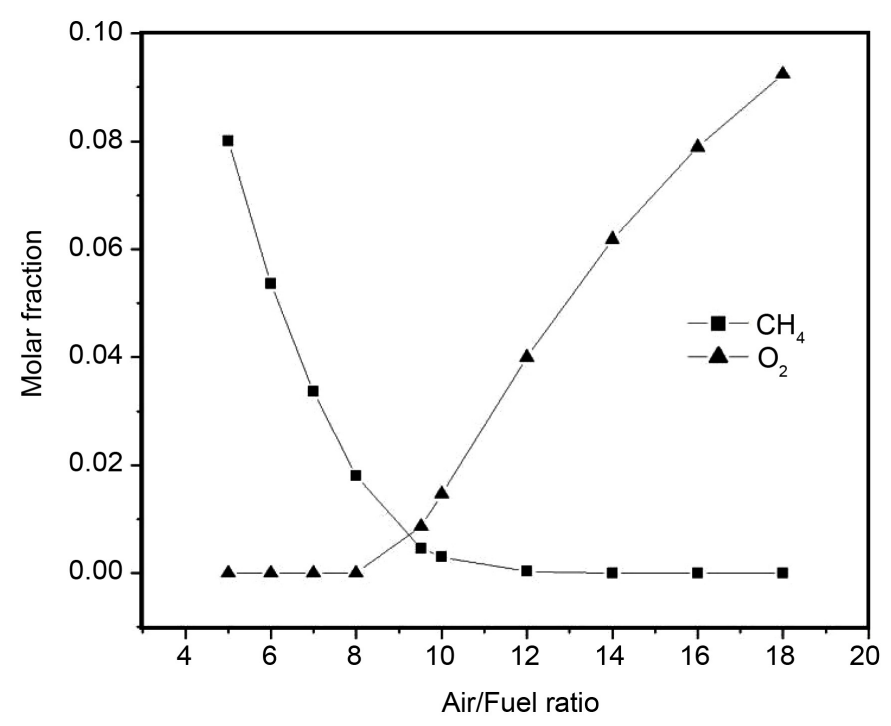

Figure 2. Exhaust gas composition for $1.2 \mathrm{~m}$ of burner height as function of the Air/Fuel ratio.

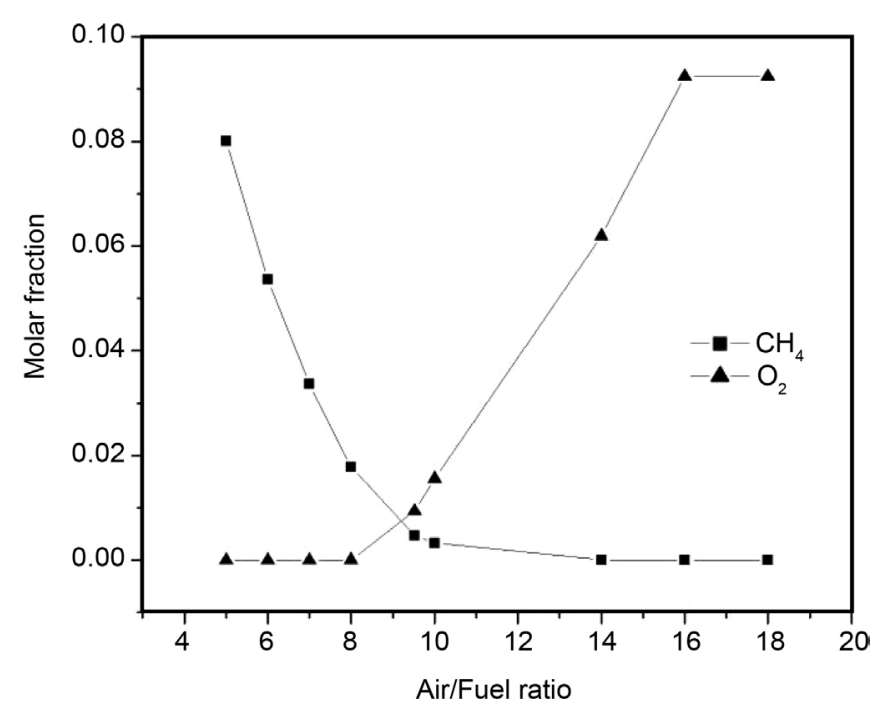

Figure 3. Exhaust gas composition for $1.4 \mathrm{~m}$ of burner height as function of the Air/Fuel ratio. 


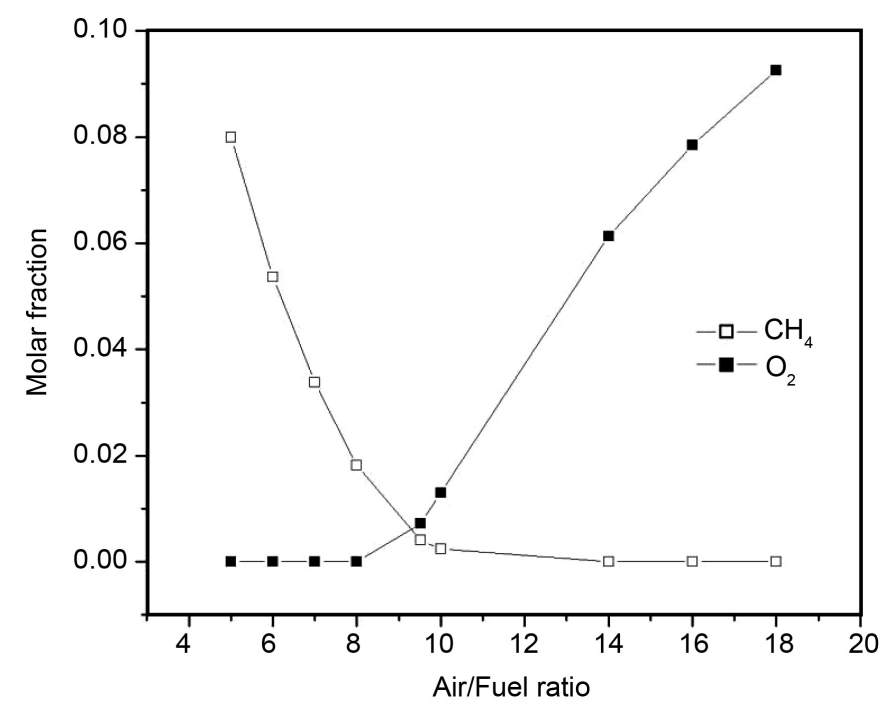

Figure 4. Exhaust gas composition for $1.6 \mathrm{~m}$ of burner height as function of the Air/Fuel ratio.

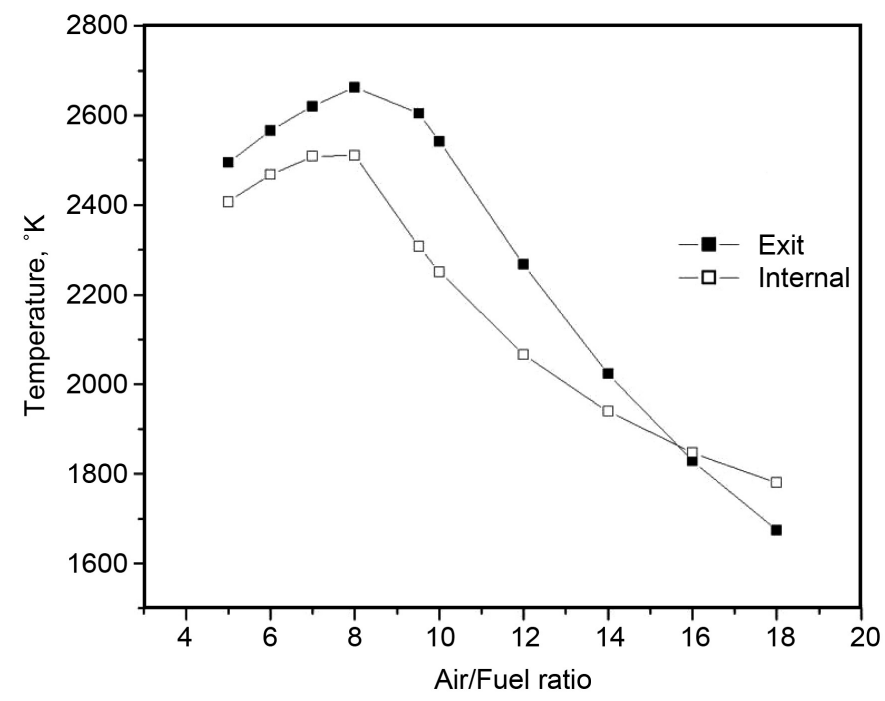

Figure 5. Exit gas and average internal temperatures for $1.2 \mathrm{~m}$ of burner height as function of the Air/Fuel ratio.

AFRC, the opposite behavior occurs, i.e. the exit temperature is every time lower than the internal temperature as AFR is increased. The value of AFRC strongly depends on the burner position, as is inferred from Figures 5-7: AFRC $=16$ for 1.2 of burner height, $\mathrm{AFRC}=14$ for $1.4 \mathrm{~m}$ of burner height, and AFRC $=12$ for $1.6 \mathrm{~m}$ of burner height.

Figure 8 indicates that the average internal furnace temperature depends on the burner position for values of AFR > TA. It is seen in this figure that for a burner height of $1.2 \mathrm{~m}$ the average internal temperature in the furnace is minimal. Given that the height of the solid charge is $1 \mathrm{~m}$, it is possible that for the burner position of $1.2 \mathrm{~m}$ the solid charge would be directly exposed to the burner flame, and then the heat transfer from the flame to the solid charge would be 


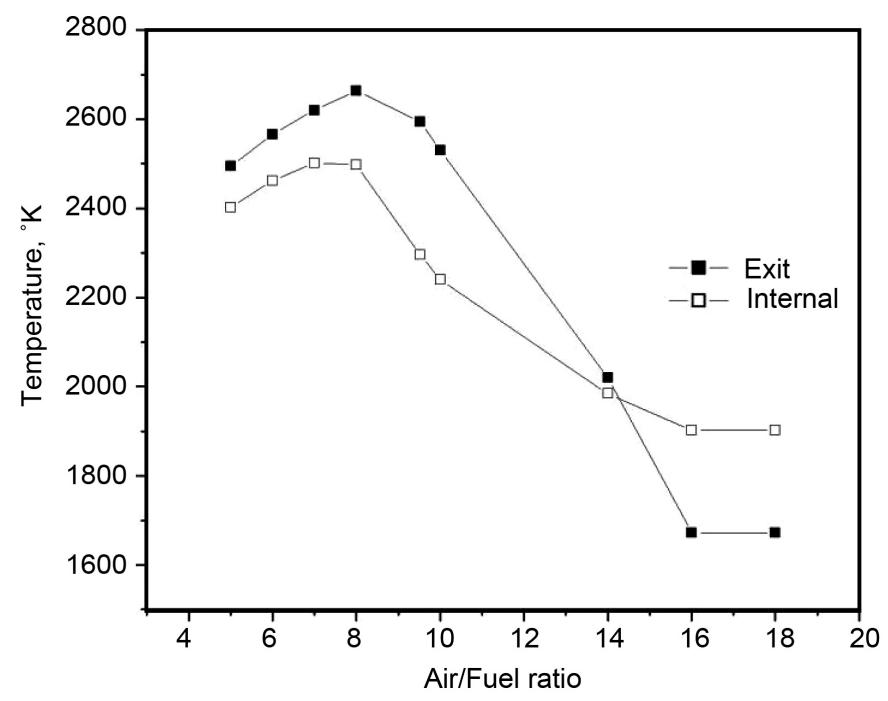

Figure 6. Exit gas and average internal temperatures for $1.4 \mathrm{~m}$ of burner height as function of the Air/Fuel ratio.

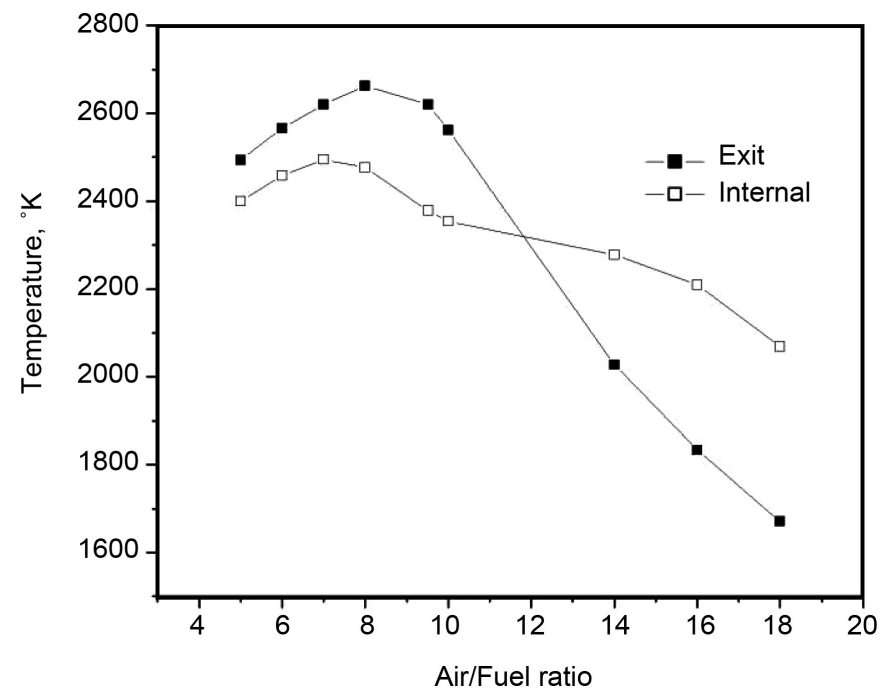

Figure 7. Exit gas and average internal temperatures for $1.6 \mathrm{~m}$ of burner height as function of the Air/Fuel ratio.

greater than for the other burner positions and the furnace becomes cooler. Even when heat transfer could be maximized by the contact of the flame with the solid charge, this situation is undesirable given that the solid charge would be over-oxidized.

\section{Results with Thermal Load}

In the numerical experiments with thermal load, the value of this parameter was varied from 80,000 to $120,000 \mathrm{~W} / \mathrm{m}^{2}$ and the Air/Fuel ratio was maintained constant at a value of 10. Results are displayed in Figure 9 and Figure 10, which show the influence of the thermal load on the exhaust gas temperature and the average internal temperature, respectively. In these figures it can appreciated 


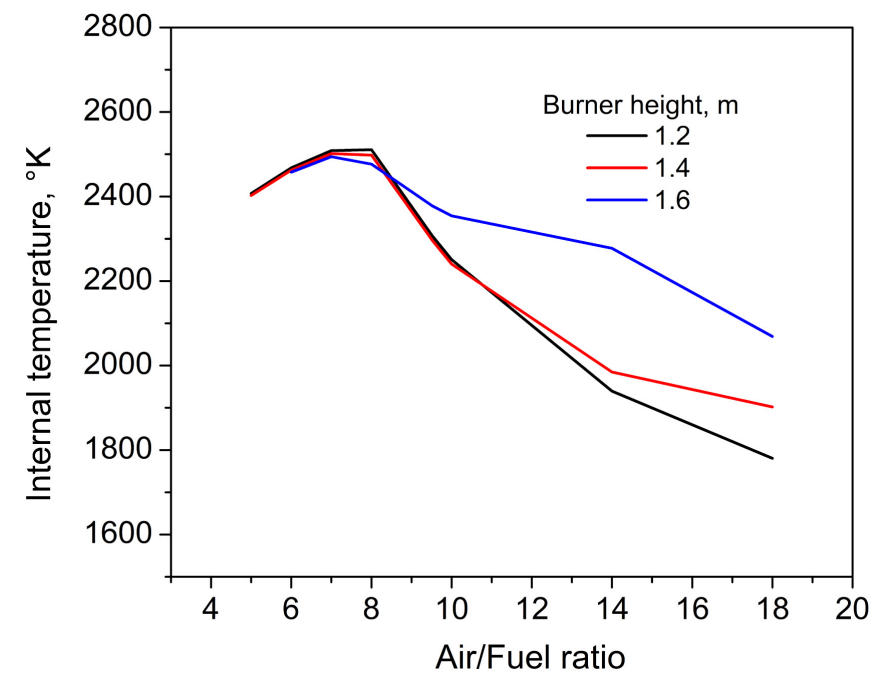

Figure 8. Average internal temperature as function of the Air/Fuel ratio for the burner height considered.

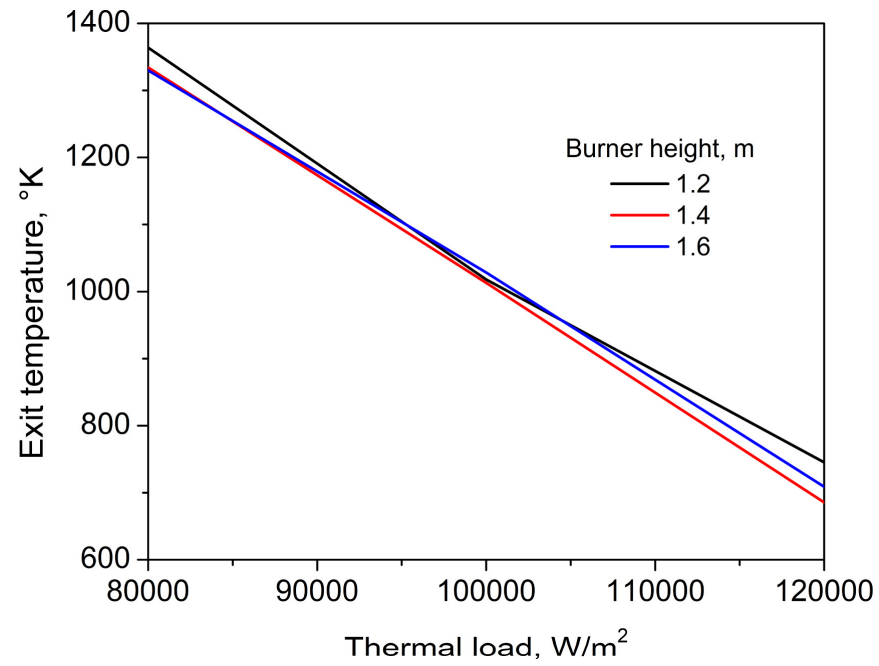

Figure 9. Exhaust gases (exit) temperature as function of thermal load for the burner height considered.

that both temperatures depend in a linear and decreasing way on the thermal load. As the thermal load is increased, the exit and the internal temperatures decrease linearly. However, it is noted that for higher thermal loads both temperatures are slightly increased as the height of the burner is decreased, but not in a significant way.

\section{Conclusions}

A numerical analysis of a batch-type reheating furnace with and without thermal load was carried out using the Computational Fluid Dynamics technique. From the numerical experiments, the following conclusion can be established:

1) Burner position does not change in a significant way the methane and oxygen molar fraction in the exhaust gases. 


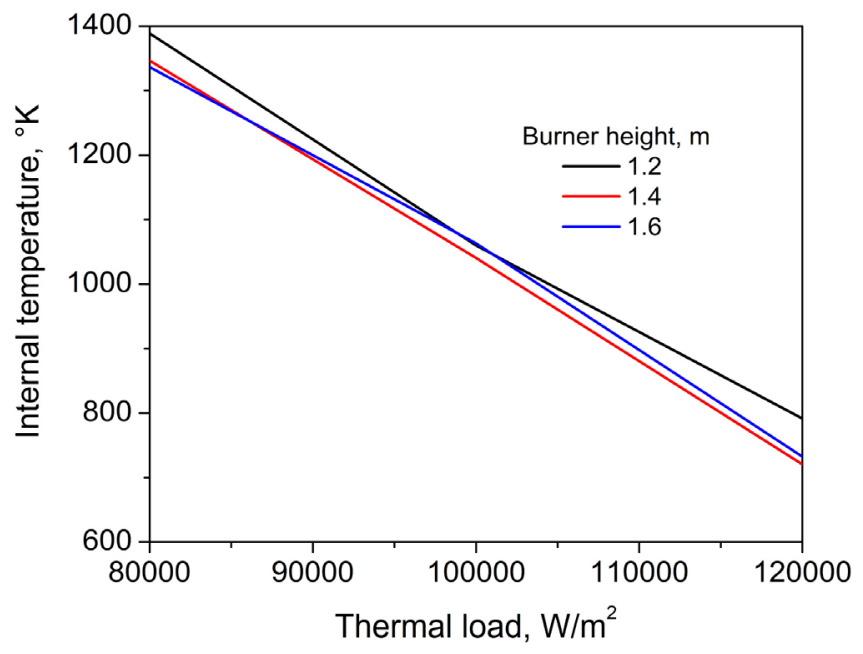

Figure 10. Average internal temperature as function of thermal load for the burner height considered.

2) The exit temperature is greater than the average internal temperature until a certain critical value of the Air/fuel ratio is reached. If this critical value is exceeded, the opposite behavior occurs; i.e. the exit temperature is every time lower than the internal temperature.

3) The critical value of the Air/Fuel ratio strongly depends on the burner position.

4) In absence of thermal load, the average internal furnace temperature is increased as the burner height is increased.

5) With thermal load in the furnace, as the thermal load is increased, the exit and the internal temperatures decrease linearly.

Future work must include heat losses through furnace walls and 3D CFD simulations.

\section{Conflicts of Interest}

The authors declare no conflicts of interest regarding the publication of this paper.

\section{References}

[1] Muhammed, F., Raazick, M., Noorshan, M., Rashid, K., Rumaisa, C.M., Sanmishal, P.K. and Jibi, R. (2016) Energy Efficiency Analysis of an Industrial Reheating Furnaces and Investigating Efficiency Enhancing Opportunities: Literature Review. International Journal of Engineering and Innovative Technology, 6, 21-28.

[2] Dong, W. (2000) Design of Advanced Industrial Furnaces Using Numerical Modeling Method. Doctoral Thesis, Royal Institute of Technology, Stockholm.

[3] Ahmad, A.F. (2009) CFD Simulation of Temperature Distribution and Heat Transfer Pattern inside C492 Combustion Furnace. Bachelor Thesis, Universiti Malaysia Pekan.

[4] Wu, B., Roesel, T., Arnold, A.M., Xu, Z., Arnold, E., Downey, G. and Zhou, C.Q. (2008) CFD Analysis of a Batch-Type Reheating Furnace for Improved Heating 
Performance. ASME 2008 International Mechanical Engineering Congress and EXposition, Boston, MA, October 31-November 6, 139-148.

[5] Chougule, V.N., Daud, O.F., Gupta, G.R., Shelke, V.H. and Ugale, R.V. (2013) Numerical Analysis of Combustion Furnace Performance by CFD. Second National Conference on Recent Developments in Mechanical Engineering, Pune, April 26-27, 72-79.

[6] Danon, B., Cho, E.S., de Jong, W. and Roekaerts, D.J.E.M. (2011) Numerical Investigation of Burner Positioning Effects in a Multi-Burner Flameless Combustion Furnace. Applied Thermal Engineering, 31, 3885-3896. https://doi.org/10.1016/j.applthermaleng.2011.07.036

[7] Bird, R.B, Stewart, W.E. and Lightfoot, E.N. (2002) Transport Phenomena. 2nd Edition, John Wiley \& Sons, New York, NY.

[8] Thomas, B.G., Yuan, Q., Sivaramakrishnan, S., Shi, T., Vanka, S.P. and Assar, M.B. (2001) Mathematical Modeling of Iron and Steel Making Processes. Comparison of Four Methods to Evaluate Fluid Velocities in a Continuous Slab Casting Mold. ISIJ International, 41, 1262-1271. https://doi.org/10.2355/isijinternational.41.1262

[9] Fluent 6.1 (2003) User's Guide. Lebanon, NH. 